\title{
Evaluating composting and co-composting kinetics of various agro-industrial wastes
}

\author{
Hani Abu Qdais ${ }^{1}$ Mohamad Al-Widyan ${ }^{2}$
}

Received: 19 March 2016/ Accepted: 10 August 2016/Published online: 26 August 2016

(C) The Author(s) 2016. This article is published with open access at Springerlink.com

\begin{abstract}
Purpose Agro-industrial wastes are posing serious challenges for the agro-industries. Composting and co-composting of such wastes will lead to converting such wastes into a useful product that will serve as a soil conditioner. The present research investigated the kinetics of composting and co-composting of several agro-industrial wastes.

Methods Seven pilot scale composting and co-composting piles of substrates from grain dust (GD), coffee-processing waste (CPW) and olive mill waste (OMW) were tested. Temperature and moisture content of the piles were monitored during the composting process and adjusted whenever necessary.

Results The biodegradation kinetics was found to be of first order for all composting and co-composting piles. As judged by the value of the reaction rate constant, and the temperature of the piles, the biodegradability of the grain dust was the highest among all composting piles, followed by the coffee-processing residue and finally the fresh olive mill waste. As for the co-composting, the highest degradability was noticed in the pile that was composed of grain dust and coffee-processing waste followed by that of grain dust mixed with dry olive mill waste, and then followed by
\end{abstract}

Hani Abu Qdais

hqdais@just.edu.jo

Mohamad Al-Widyan

widyan@just.edu.jo

1 Civil Engineering Department, Jordan University of Science and Technology, P.O Box 3030, Irbid 22110, Jordan

2 Mechanical Engineering Department, Jordan University of Science and Technology, P.O Box 3030, Irbid 22110, Jordan coffee-processing waste and dry olive mill waste and finally by grain dust with fresh olive-processing waste. Conclusions Composting and co-composting of agro-industrial wastes is a low cost and an environmentally friendly waste management option for solving the problem of the disposal of such waste. The study revealed that all piles followed first-order kinetics with different biodegradability rates.

Keywords Agro-industrial waste $\cdot$ Composting $\cdot$ Cocomposting $\cdot$ Kinetics

\section{Introduction}

Throughout the world, agro-industrial sector is subjected to tighter and stricter environmental regulations, and the need to introduce effective monitoring and handling systems. Treatment and safe disposal of the ever increasing amounts of industrial by-products pose continual energetic, economic and environmental challenges to enterprises (Castaldi and Melis 2002; Rashad et al. 2010).

In many developing countries, organic wastes including agro-industrial wastes, among other waste streams, are traditionally directly incinerated or deposited in landfills resulting in the production of significant amounts of greenhouse gases, besides removing valuable and oftentimes a limited land resource (Zhang et al. 2013). Unless managed properly, agro-industrial waste may pose both environmental and health problems (Sharma et al. 1997). For example, Abu Qdais and Alshraideh (2016) reported that there are 118 olive oil mills in Jordan producing annually about 35,561 tons of solid waste from the olive oil industry. Deterioration of natural water bodies due to olive oil mill wastes is a serious problem as reported by Azbar 
(2004) and Alburquerque et al. (2006). In contrast, composting and/or co-composting of organic wastes is considered as an effective component in any integrated waste management strategy (Bari and Koenig 2002), and considered as an environmentally friendly option for treatment of such wastes (Korner et al. 2003). The term "composting" refers to the controlled decomposition and stabilization of organic wastes by biological means under aerobic conditions (Dees and Ghiorse 2001; Paredes et al. 1996). Co-composting, however, is the simultaneous composting of two or more types of waste material (Das et al. 2011; Petric et al. 2012), with the potential added benefit of enhancing end compost quality (Paredes et al. 1996).

In addition to being a low-cost, environment-friendly process, composting benefits also include reduction of volume, weight, moisture content, potential odor, and pathogens, as well as increasing potential nutrients of the waste (Scheutz et al. 2011). Most importantly, perhaps, the end product can be used as a useful soil amendment: fertilizer and/or soil conditioner (Huang et al. 2006; Iqbal et al. 2010), besides other uses such as pellets for fuel (Zajonc et al. 2014), isolating various microbial control agents (Larkin and Tavantzis 2013), and potential heat recovery from the composting process (Al-Widyan et al. 2008). However, compost from agro-industrial wastes in particular is more reliable and is considered "clean biowaste," and thus may be utilized in crop systems as a fertilizer or soil conditioner with a good quality. (Ben Rebah et al. 2007). Olive milling wastes (OMW), grain dust (GD) from grain handling facilities, and coffee-processing wastes (CPW) represent three major agro-industrial waste streams. Meanwhile, in many regions like the Mediterranean, where agriculture is a major activity, soil quality has witnessed continued deterioration due to the widespread implementation of inadequate agricultural production techniques that constitute a serious threat to the sustainability of this vital sector (Zalidis et al. 2002; Lasaridi et al. 2006; Reynolds and Borlaug 2006; Verhulst et al. 2010; Martínez-Blanco et al. 2011). In addition, soils in this region in general suffer from low levels of organic content that is most commonly substituted by chemical fertilizers that have short-term impact on yield, typically up to 2 years, but fail to improve soil physical properties (Shiralipour et al. 1992; Carpenter-Boggs et al. 2000). Meanwhile, the Mediterranean has traditionally been and is projected to continue to be the world's major olive producer, although olive industry is expanding beyond the Mediterranean into new territories such as Australia, for instance, where olive culture is witnessing a rapid growth.

However, before applying compost to crop systems, due care should be taken to make sure that the compost is of a good quality, sufficiently mature and stable (Bachert et al. 2008). In addition to the $C / N$ ratio, $\mathrm{pH}$, and the physical structure of the substrate, such factors as aeration rate, temperature, and moisture content play a vital role in effective composting (Korner et al. 2003; Huang et al. 2004).

In light of all the above, this study was initiated by establishing a total of seven pilot scale indoor and outdoor static composting windrows that consisted of three agro-industrial waste streams, namely olive cake (the solid by-product of olive processing), grain dust, and coffee-barley, or mixtures thereof. The purpose was to examine the composting and co-composting kinetics by monitoring the degradation process in terms of volatile solids (VS) content, temperature and moisture variations of the windrows over the composting periods. Composting kinetics modeling is necessary to design and operate composting facilities that comply with strict market demands and stringent environmental regulations (Hamelers 2004). This can be achieved once the composting kinetics is well understood. (Hamoda et al. 1998). Proper modeling of the progress of substrate degradation is of great importance in the prediction of operating variable of the composting process. One of the most commonly used approaches in modeling the composting kinetics is the substrate degradation models, where the independent variable is either the quantity or concentration of the substrate remaining. In the present study, remaining amount of the substrate was selected as indicator to model the composting kinetics and to find out which reaction order the composting kinetics follow.

\section{Materials and methods}

As indicated earlier, this study involved three agro-industrial waste types, namely, OMW, GD, and CPW, as well as various two-material mixture combinations thereof. Sufficient amounts of each substrate were collected and brought to the laboratory in plastic bags and maintained under prevailing laboratory conditions. Fresh and dry OMW and GD were brought in from, respectively, an olive mill and a major national grain storage facility, both located in the vicinity of Jordan University of Science and Technology (JUST) campus. As for CPW, it was gathered from an instant coffee factory in Amman about $100 \mathrm{~km}$ away from JUST campus.

Before being subjected to composting, initial contents of moisture and volatile solids were determined for all samples. Moisture content was determined by oven drying at $105{ }^{\circ} \mathrm{C}$ for about $24 \mathrm{~h}$, while volatile solids were determined by incinerating the dry samples in a muffle furnace 
Table 1 Initial moisture content and volatile solids for the organic wastes used in the study

\begin{tabular}{lll}
\hline Raw material & $\begin{array}{l}\text { Moisture content } \\
(\% \text { w.b. })\end{array}$ & $\begin{array}{l}\text { Volatile solids } \\
(\%)\end{array}$ \\
\hline Dry grain dust & 8.9 & 72.45 \\
Dry olive milling waste & 8 & 55 \\
Coffee-processing waste & 62.3 & 77.73 \\
Fresh olive milling waste & 61.3 & 87.40 \\
\hline
\end{tabular}

Table 2 Information on the composting and co-composting piles

\begin{tabular}{llll}
\hline Pile & Condition & $\begin{array}{l}\text { Average ambient } \\
\text { temperature }\left({ }^{\circ} \mathrm{C}\right)\end{array}$ & $\begin{array}{l}\text { Duration of } \\
\text { composting } \\
\text { (days) }\end{array}$ \\
\hline GD & Indoor & 27 & 38 \\
CPW & Indoor & 27 & 60 \\
GD + CPW & Indoor & 27 & 38 \\
GD + OMW & Outdoor & 31 & 48 \\
CB + OMW & Outdoor & 31 & 48 \\
GD + fresh OMW & Indoor & 13 & 70 \\
Fresh OMW & Indoor & 13 & 70 \\
\hline
\end{tabular}

at $550{ }^{\circ} \mathrm{C}$ for $1 \mathrm{~h}$. Values of these parameters for each type of waste are listed in Table 1. It can be observed that the highest volatile solids content is in fresh olive milling waste $(87.40 \%)$, while it is the lowest in dry olive milling waste $(55 \%)$. This can be explained by the fact that the dry olive milling waste has lost some of its volatile solids contents during the drying process.

The study involved a total of seven laboratory scale composting piles (windrows). Particularly, three indoor piles were prepared; one of which was of GD, the other of $\mathrm{CPW}$, and the third involved a mixture of GD and CPW. Two more outdoor piles were established; one of a mix of GD and dry OMW, and the other consisted of a mix of CB and dry OMW. The remaining two were indoor piles; one consisted of a mix of fresh OMW and GD, and the other was purely fresh OMW. Detailed information of each composting pile is provided in Table 2 .

It may be noted that composting activity of CPW extended over a longer period of time compared to either GD or GD + CPW mix at the same temperature. This is because the active composting period was the parameter that dictated the termination of the experiment, rather than the composting duration itself.

Following Rynk (1992), all piles were passively aerated windrow type with low parabolic shape. The geometric characteristics of the piles used in this study are depicted in Fig. 1. In the case of mixed piles, equal amount of each of the two materials would be piled together and gradually wetted and continuously and thoroughly mixed manually in order, so as, to secure a 50:50 mix and, to achieve optimum initial moisture content of about $60 \%$ (w.b.).

In order to avoid undesirable consequences of anaerobic pockets formation within the piles (Bachert et al. 2008) and maintain aerobic conditions, pile aeration was provided by using perforated pipes that were inserted at the bottom of each pile at a regular distance. Specifically, five $10-\mathrm{cm}$ diameter PVC perforated pipes were utilized to supply air to the passively aerated windrows. Each pipe had two rows of $1.25 \mathrm{~cm}$ diameter holes that were $30 \mathrm{~cm}$ apart along the pipes. To prevent blockage of the holes, pipes were covered by sawdust with holes made facing downward to avoid the direct cooling effect of air (Rynk 1992). Besides aeration, piles were manually wetted and turned once their temperature dropped below $40{ }^{\circ} \mathrm{C}$ and/or moisture content dropped below $40 \%$ (Tiquia et al. 1997). Table 3 shows the wetting and turning frequency of the piles throughout the composting period.

Throughout the data collection period, the ambient temperature was recorded on a daily basis. In addition and in light of the absence of any standard in this respect (Wichuk and McCartney 2008; Isobaev et al. 2014), it was deemed appropriate to record the temperature at four locations along the pile at $60,120,180$, and 240 from the pile's end. At each of these locations, temperature was measured on a daily basis at three different points within the windrow at a depth of $40-50 \mathrm{~cm}$ into the compost mass. In each windrow, four locations would be specified on day 1 of the process for moisture and volatile solids sampling and measurement. Using and sticking to these same locations throughout the process, moisture measurement was conducted twice a week during off-winter and once a week during winter. Volatile solid contents were determined one a week from these same four locations. Each moisture/volatile solids reading was for a mixture of the four samples from the four locations. All temperature measurements were made by thermocouples and digital thermometers.

\section{Volatile solids}

Volatile solids (VS) determination was accomplished using ignition method (Tchobanoglous et al. 1993). Samples of substrate were withdrawn from the compost piles on a weekly basis and subjected to drying and ignition in a muffle furnace. Comparing the volatile solid concentration at any time to the initial volatile solids in each pile was used to calculate the volatile solids index according to the following equation:

Volatile solids index $=\frac{\text { Volatile solids content }}{\text { Initial volatile solids content }}$ 
Fig. 1 Dimensions and shape of the aerated composting pile

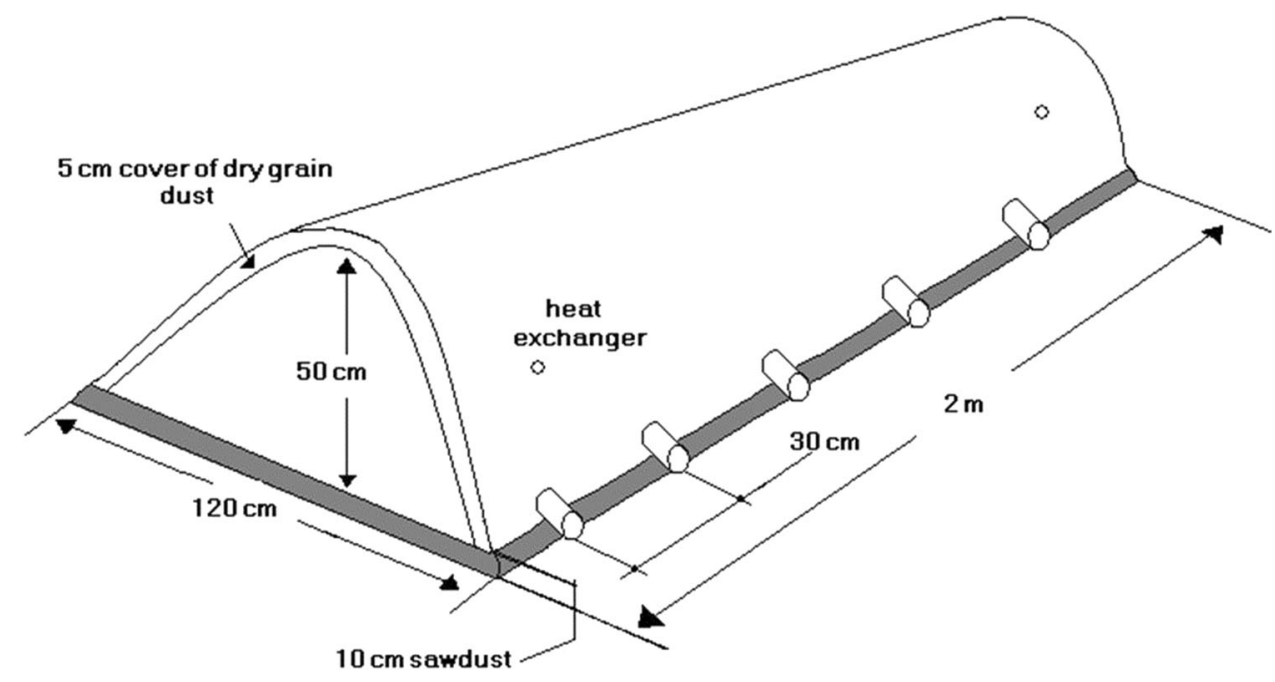

\begin{tabular}{lllll}
\hline Pile & \multicolumn{4}{l}{ Turning frequency (day no.) } \\
\cline { 2 - 5 } & First turn & Second turn & Third turn & Fourth turn \\
\hline GD & 24 & 31 & 38 & - \\
CPW & 24 & 38 & 52 & 54 \\
GD + CB & 24 & 31 & 38 & - \\
GD + dry OMW & 14 & 31 & 41 & - \\
CPW + dry OMW & 10 & 14 & 18 & - \\
GD + fresh OMW & 11 & 23 & 60 & - \\
Fresh OMW & 11 & 23 & 60 &
\end{tabular}

\section{Results and discussions}

\section{Temperature-time history}

The variation of compost mass temperature over time for the three groups of windrows is shown in Figs. 2, 3, 4. These figures indicate that all runs showed the general temperature-time pattern of a composting pile and were mostly in the thermophilic range with a maximum pile temperature of about $65{ }^{\circ} \mathrm{C}$, which is in agreement with values reported in literature (Mbuligwe et al. 2002; Weppen 2001).

Close examination of the figures reveals that the indoor piles (Fig. 2) experienced the most vigorous composting. Figure 2 shows that composting time of the indoor pile maintained for longer duration followed by outdoors piles. This trend may be attributed to the ambient temperature which was about $27{ }^{\circ} \mathrm{C}$ for laboratory ambient conditions compared to more than $30.4{ }^{\circ} \mathrm{C}$ for outdoor ambient air temperature. For comparison Table 3 shows composting conditions (i.e., indoor or outdoor), composting times and ambient temperature for each pile.

It should be noted that the discontinuities appearing in the figures as sharp increases in pile temperature particularly in Figs. 2 and 3 indicate an incident of turning and

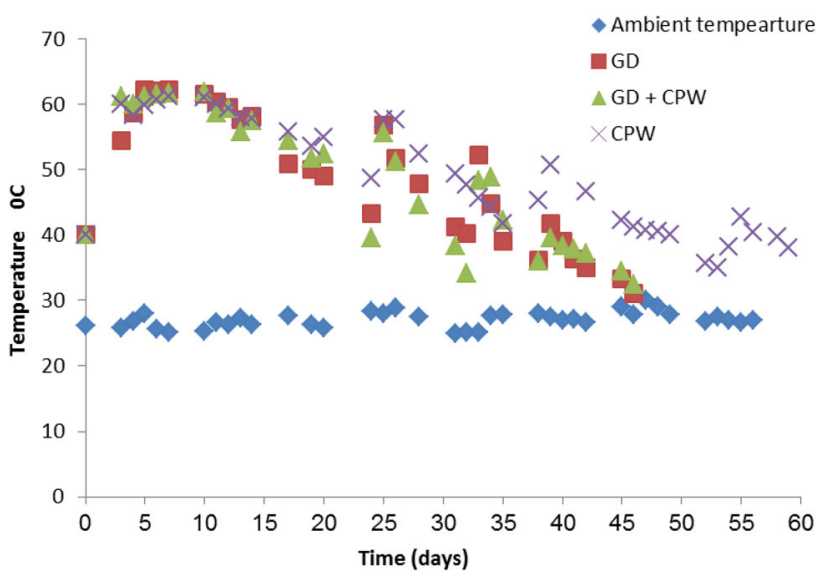

Fig. 2 Temperature variation for the indoor piles over the composting period

wetting of the piles. Still, however, it seems that for this particular waste material and study conditions, once pile temperature experiences the first significant drop, turning and wetting effect only a short-lived temperature rise that declines relatively quickly thereafter.

As may be seen in Figs. 5, 6, 7 where a sudden overshoot in pile moisture indicates an incident of wetting and turning 


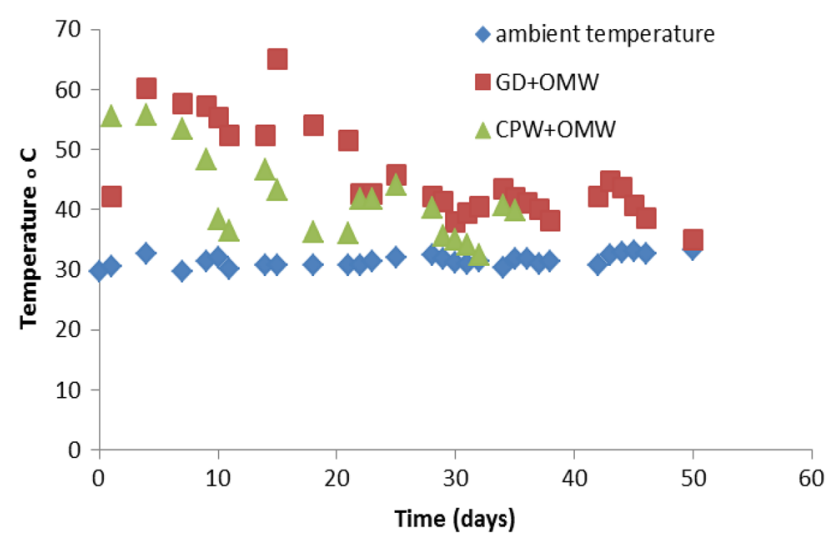

Fig. 3 Temperature variation for the outdoor piles over the composting period

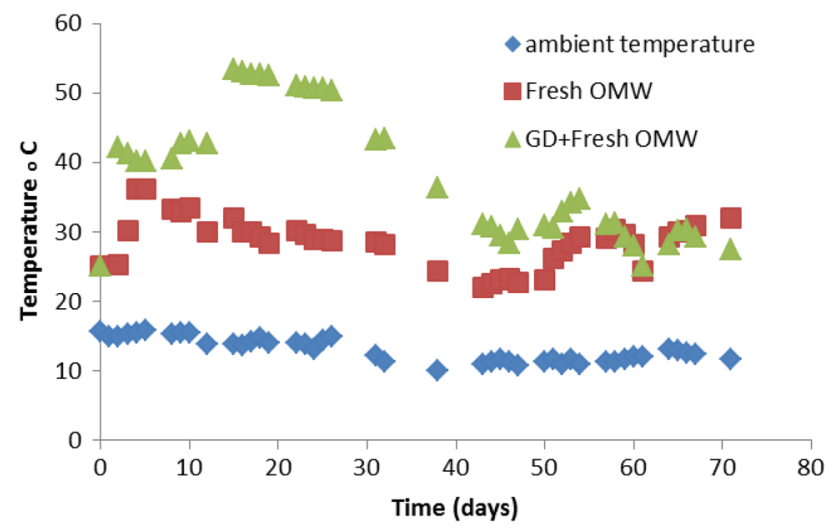

Fig. 4 Temperature variation for indoor piles (winter) over the composting time

\section{Pile moisture variation}

The variation of piles moisture content with composting time is depicted in Figs. 5, 6, 7 for the three runs. Given the significant effect of pile moisture on composting and the fact that a minimum of about $40 \%$ moisture should be maintained for active composting, Figs. 5, 6, 7 indicate that under the prevailing conditions of this work, pile moisture diminished relatively quickly for outdoor piles compared to the indoor piles, although indoor piles that were made in winter period have a relatively slow drying rate. This is expected in light of the fact that ambient temperature is significantly lower in winter than in summer, while humidity is much higher.

\section{Composting kinetics}

Figures $8,9,10$ show the degradation progress during the composting process by monitoring the volatile solids index. It can be observed that for all composting piles the degradation process follows an exponential decay trend as confirmed by Fig. 11 that shows the correlation of the exponential function for the first group of composting piles

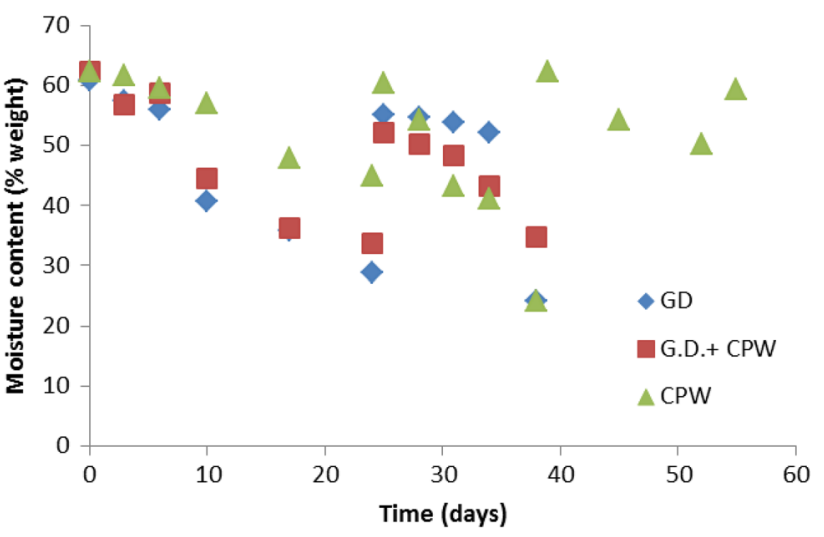

Fig. 5 Moisture variation in the indoor piles over the composting period

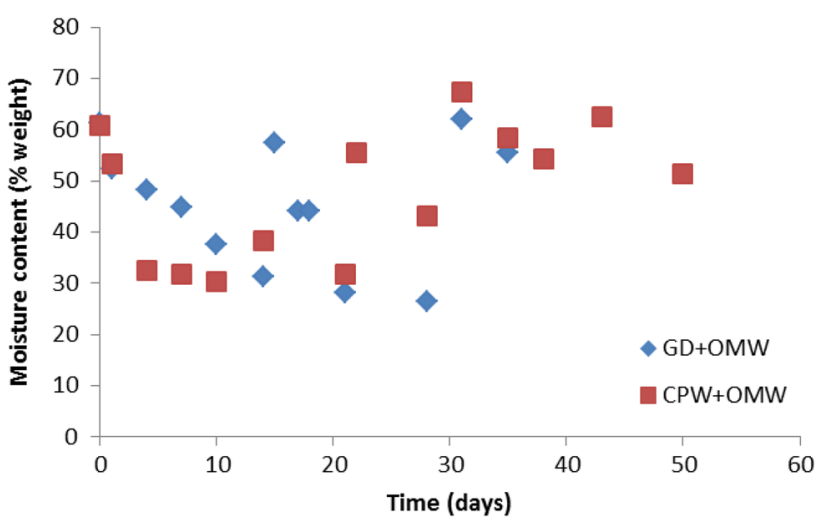

Fig. 6 Moisture variation in the outdoor piles over the composting period

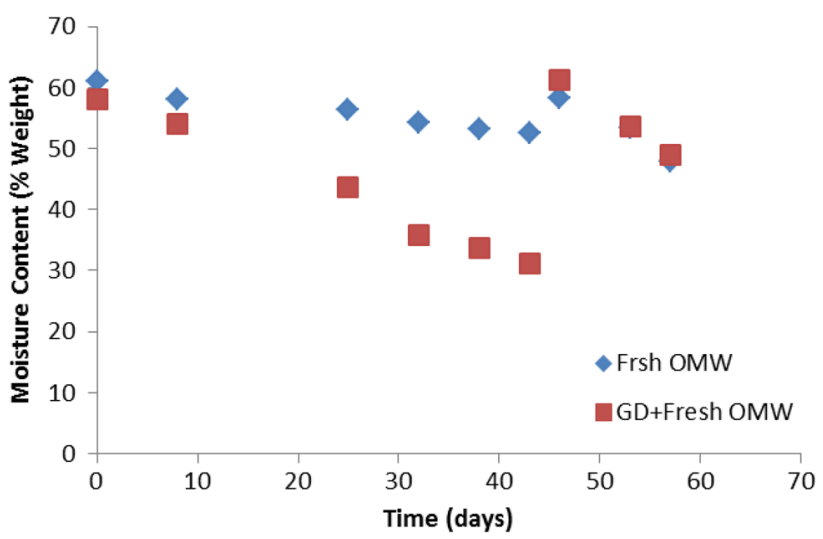

Fig. 7 Moisture variation in the indoor piles over the composting period (winter)

with high value of coefficient of determination $\left(R^{2}\right)$, which was $0.99,0.98$ and 0.88 for grain dust, grain dust with coffeeprocessing waste and coffee-processing waste, respectively.

Since the degradation of organic matter as a function of time follows first-order kinetics, the rate of degradation can be expressed by the following equation: 


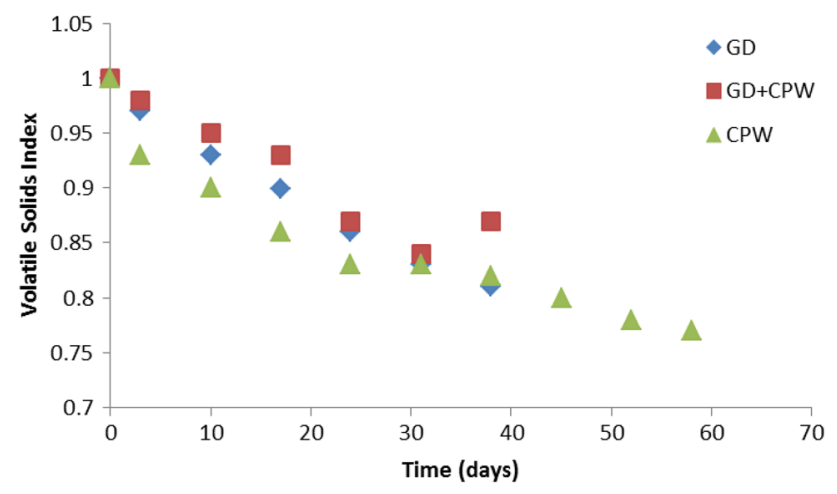

Fig. 8 Volatile solids index for indoor piles

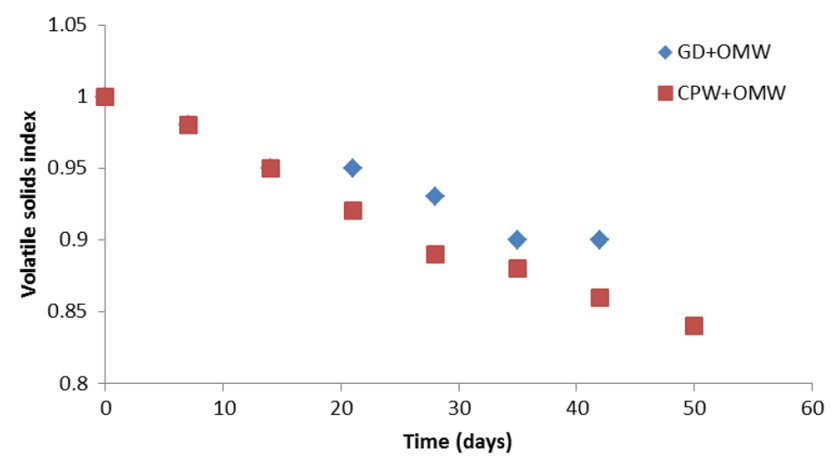

Fig. 9 Volatile solids index for outdoor piles

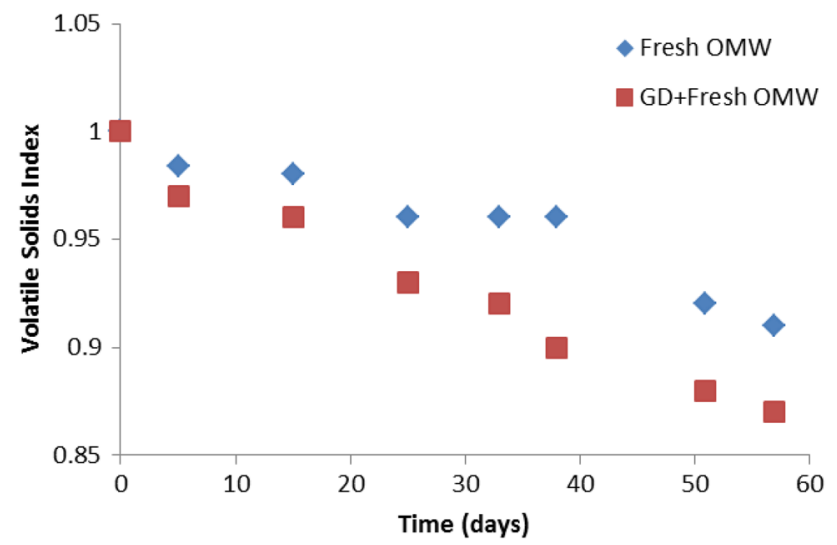

Fig. 10 Volatile solids index for indoor piles (winter)

$\mathrm{dVS} / \mathrm{d} t=-k \mathrm{VS}$

where:

VS is the concentration of biodegradable volatile solids at any time in grams

$t$ is the time in days

$k$ is the first-order reaction rate constant in $\mathrm{day}^{-1}$

Integrating Eq. 2 by letting $\mathrm{VS}=\mathrm{VS}_{0}$ at $t=0$, the concentration of organic matter at any time in the compost mass can be expressed as follows:

$\operatorname{Ln}\left(\mathrm{VS} / \mathrm{VS}_{0}\right)=-k t$

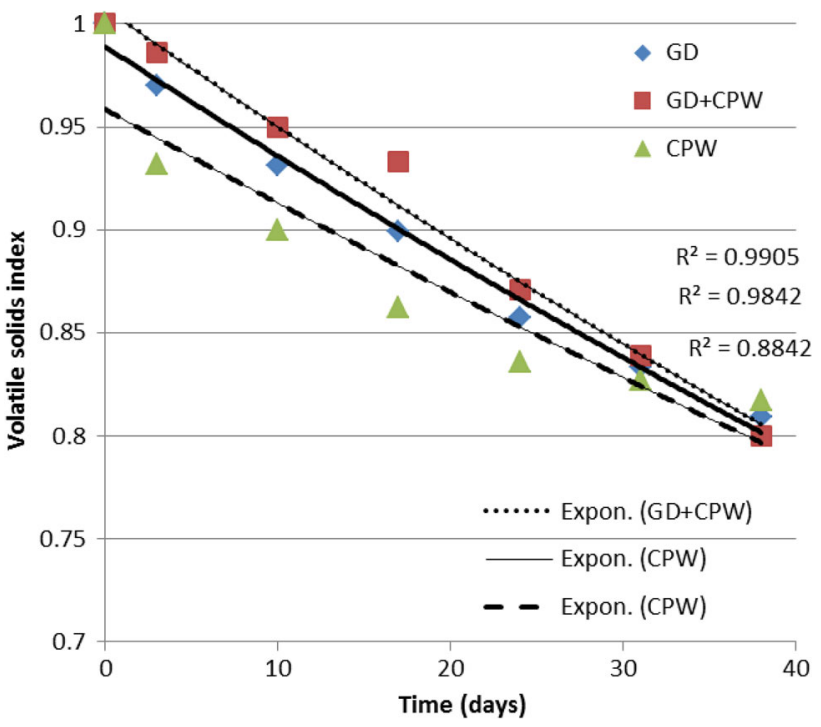

Fig. 11 Exponential correlations of the volatile solids for the first group of composting piles

Table 4 Values of first-order reaction rate constant for each composting pile

\begin{tabular}{llll}
\hline $\begin{array}{l}\text { Compost } \\
\text { substrate }\end{array}$ & $\begin{array}{l}\text { Reaction rate } \\
\text { constant } k\left(\mathrm{~d}^{-1}\right)\end{array}$ & $\begin{array}{l}\text { Duration of } \\
\text { composting (days) }\end{array}$ & $\begin{array}{l}\text { Indoor/ } \\
\text { outdoor }\end{array}$ \\
\hline GD & 0.0055 & 38 & Indoor \\
CPW & 0.0039 & 60 & Indoor \\
GD + CPW & 0.0045 & 38 & Indoor \\
GD + OPW & 0.0036 & 48 & Outdoor \\
CPW + fresh & 0.0024 & 48 & Outdoor \\
OMW & & 70 & Indoor \\
GD + fresh & 0.0022 & 70 & Indoor \\
OMW & & & \\
Fresh OMW & 0.0015 & &
\end{tabular}

During the composting process, samples of composted substrates were withdrawn from the piles on a weekly basis and subjected to ignition process to determine the volatile solids content of the piles. By knowing the initial volatile solids content and following the change in the volatile solids with time, and by applying the first-order reaction equation, it was possible to calculate the reaction rate constant $(k)$ for each pile. Values of the reaction rate constant are presented in Table 4

Volatile solids are used as an indicator of organic matter content and their measurement can serve as a quick and reliable indicator of organic matter degradation kinetics during the composting process.

Examining Table 4 carefully, it can be observed that the compost pile that has the highest biodegradability is the grain dust with a reaction rate constant of $0.0055 \mathrm{~d}^{-1}$, followed by coffee-processing waste and fresh olive 
milling waste with reaction rate constants of 0.0039 and $0.0015 \mathrm{~d}^{-1}$, respectively. On the other hand, among the cocomposting piles, the grain dust with coffee-processing waste had the highest biodegradability with reaction rate constant of $0.0045 \mathrm{~d}^{-1}$, followed by grain dust with dry olive-processing waste that had a rate constant of 0.0036 $\mathrm{d}^{-1}$, and coffee-processing waste plus fresh olive milling waste with rate constant of $0.0024 \mathrm{~d}^{-1}$ and finally the grain dust with fresh olive milling waste of $0.0022 \mathrm{~d}^{-1}$. This is also evident by the higher value of temperature that was achieved in the grain dust piles, which resulted from the microbial respiration during the biodegradation process. This implies that the grain dust is a much easier biodegradable substrate than the others, while the olive cake both old and fresh had the lowest biodegradability. This is in agreement with other researchers who reported a relatively slow biodegradation rate of olive waste (Alburquerque et al. 2006). This is expected since the olive residues contain phenolic and complex lipids which are phytotoxic and stable compounds that inhibit microbial activity and slow the biodegradation process.

\section{Conclusions and recommendations}

Information on substrate biodegradability and its composting kinetics is important for planning and design of the composting facility. The composting and co-composting experiments on a pilot scale revealed that all agro-industrial wastes followed first-order kinetics during composting and co-composting processes. However, the substrates differ in biodegradability rate. Grain dust had the highest biodegradability, while the olive cake in dry and wet status had the lowest biodegradability. For future research, it is recommended to test the produced compost from agro-industrial waste in nurseries and field to check its capability in amending the soil properties and improving fertility.

Acknowledgment The authors would like to thank Jordan University of Science and Technology (JUST) for providing the testing facility and infrastructure support for this study.

Open Access This article is distributed under the terms of the Creative Commons Attribution 4.0 International License (http://crea tivecommons.org/licenses/by/4.0/), which permits unrestricted use, distribution, and reproduction in any medium, provided you give appropriate credit to the original author(s) and the source, provide a link to the Creative Commons license, and indicate if changes were made.

\section{References}

Abu Qdais H, Alshraideh H (2016) Selection of management option for solid waste from olive oil industry using the analytical hierarchy process. J Mater Cycles Waste Manag 18(1):177-185. doi:10.1007/s10163-014-0321-3

Alburquerque JA, Gonzálvez J, García D, Cegarra J (2006) Composting of a solid olive-mill by-product ("alperujo") and the potential of the resulting compost for cultivating pepper under commercial conditions. Waste Manag 26:620-626. doi:10. 1016/j.wasman.2005.04.008

Al-Widyan M, Al-Mahasneh A, Ababneh H (2008) Heat recovery opportunities from a grain dust composting pile. J Solid Waste Technol Manag 34(3):140-148

Azbar N (2004) A review of waste management options in olive oil production. Crit Rev Environ Sci Technol 34:209-247. doi:10. 1080/10643380490279932

Bachert C, Bidlingmaier W, Surapong W (2008) Open windrow composting manual. ORBIT e. V, Weimar

Bari QH, Koenig A (2002) Measuring solid waste compost maturity: a review and practice. In: International conference on Bangladesh environment-2002, 19-21 December, 2002, Dhaka, Bangladesh

Ben Rebah F, Prevost D, Yezza A, Tyagi RD (2007) Agro-industrial waste materials and wastewater sludge for rhizobial inoculant production: a review. Bioresour Technol 98:3535-3546. doi:10. 1016/j.biortech.2006.11.066x

CarpenterBoggs L, Kennedy AC, Reganold JP (2000) Organic and biodynamic management: effects on soil biology. Soil Sci Soc Am J 64:1651-1659. doi:10.2136/sssaj2000.6451651x

Castaldi P, Melis P (2002) Composting of Posidonia oceanica and its use in agriculture microbiology of composting. Springer Verlag, Berlin Heidelberg, pp 425-434

Das M, Uppal HS, Singh R, Beri S, Mohan KS, Gupta VC, Adholeya A (2011) Co-composting of physic nut (Jatropha curcas) deoiled cake with rice straw and different animal dung. Bioresour Technol 102:6541-6546. doi:10.1016/j.biortech.2011.03.058

Dees PM, Ghiorse WC (2001) Microbial diversity in hot synthetic compost as revealed by PCR-amplified rRNA sequences from cultivated isolates and extracted DNA. Microb Ecol 35:207-216. doi:10.1111/j.1574-6941.2001.tb00805.x

George Tchobanoglous G, Hilary Theisen H, Vigil SA (1993) Integrated solid waste management: engineering principles and management issues. McGraw-Hill, New York

Hamelers HVM (2004) Modeling composting kinetics: a review of approaches. Rev Environ Sci Biotechnol 3:331-342. doi:10. 1007/s11157-004

Hamoda M, Abu Qdais H, Newham J (1998) Evaluation of municipal solid waste composting kinetics. Resour Conserv Recycl 23:209-223

Huang GF, Wong JWC, Wu QT, Nagar BB (2004) Effect of C/N on composting of pig manure with sawdust. Waste Manag 24:805-813. doi:10.1016/j.wasman.2004.03.011

Huang GF, Wu QT, Wong JWC, Nagar BB (2006) Transformation of organic matter during co-composting of pig manure with sawdust. Bioresour Technol 97:1834-1842. doi:10.1016/j.bior tech.2005.08.024

Iqbal MK, Shafiq T, Hussain A, Ahmed K (2010) Effect of enrichment on chemical properties of MSW compost. Bioresour Technol 101:5969-5977. doi:10.1016/j.biortech.2010.02.105

Isobaev P, Bouferguene A, Wichuk K, McCartney D (2014) An enhanced compost temperature sampling framework: case study of a covered aerated static pile. Waste Manag 34:1117-1124. doi:10.1016/j.wasman.2014.03.016

Korner I, Braukmeier J, Herrenklage J, Leikam K, Ritzkowski M, Schlegelmilch M, Stegmann R (2003) Investigation and optimization of composting process-test systems and practical examples. Waste Manag 23:17-26. doi:10.1016/S0956053X(02)00148-4 
Larkin RP, Tavantzis S (2013) Use of biocontrol organisms and compost amendments for improved control of soil borne diseases and increased potato production. Am J Potato Res 90(3):261-270. doi:10.1007/s12230-013-9301.8

Lasaridi K, Protopapa I, Kotsou M, Pilidis G, Manios T, Kyriacou A (2006) Quality assessment of composts in the Greek market: the need for standards and quality assurance. J Environ Manag 80:58-65. doi:10.1016/j.jenvman.2005.08.011

Martínez-Blanco J, Muñoz P, Antón A, Rieradevall J (2011) Assessment of tomato, Mediterranean production in open-field and standard multi-tunnel greenhouse, with compost or mineral fertilizers, from an agricultural and environmental standpoint. J Clean Prod 19:985-997. doi:10.1016/j.jclepro.2010.11.018

Mbuligwe S, Kassenga G, Kaseva M, Chaggu EJ (2002) Potential and constraints of composting domestic solid waste in developing countries: findings from a pilot study in Dar es Salaam, Tanzania. Resour Conserv Recycl 36:45-49

Paredes C, Bernal MP, Cegarra J, Roig A, Novarro AF (1996) Nitrogen transformation during the composting of different organic wastes. In: Van Cleemput O, Hofman G, Vermoesen A (eds) Progress in nitrogen cycling studies. Kluwer Academic Publishers, Dordrecht, pp 121-125

Petric I, Helić A, Avdić EA (2012) Evolution of process parameters and determination of kinetics for co-composting of organic fraction of municipal solid waste with poultry manure. Bioresour Technol 117:107-116. doi:10.1016/j.biortech.2012.04.046

Rashad FM, Saleh WD, Moselhy MA (2010) Bioconversion of rice straw and certain agro-industrial wastes to amendments for organic farming systems: composting, quality, stability and maturity indices. Bioresour Technol 101:5952-5960. doi:10. 1016/j.biortech.2010.02.103

Reynolds M, Borlaug N (2006) Impacts of breeding on international collaborative wheat improvement. J Agricul Sci 144:3-17. doi: $10.1017 /$ S0021859606005867

Rynk R (1992) On-farm composting handbook. NRAES-54, Ithaca, NY, USA
Scheutz C, Pedicone A, Pedersen GB, Kjeldsen P (2011) Evaluation of respiration in compost landfill biocovers intended for methane oxidation. Waste Manag 31:895-902. doi:10.1016/j.wasman. 2010.11.019

Sharma V, Candettili M, Fortuna F, Cornacchina G (1997) Processing of urban and agro-industrial residues by aerobic composting: review. Energy Convers Manag 38(5):453-478

Shiralipour A, McConnell DB, Smith WH (1992) Physical and chemical properties of soils as affected by municipal solid waste compost application. Biomass Bioenerg 3:261-266

Tiquia SM, Tam NF, Hodgkiss IJ (1997) Effects of turning frequency on composting of spent pig-manure sawdust litter. Bioresour Technol 62:37-42

Verhulst N, Govaerts B, Verachtert E, Castellanos-Navarrete A, Mezzalama M, Wall P, Chocobar A, Deckers J, Sayre K (2010) Conservation agriculture, improving soil quality for sustainable production systems. Advances in soil science: food security and soil quality. CRC Press, Boca Raton, pp 137-208

Weppen P (2001) Process calorimetry on composting of municipal organic wastes. Biomass Bioenerg 21:289-299

Wichuk KM, McCartney D (2008) Development of time-temperature probes for tracking pathogen inactivation during composting. Compos Sci Util 16(2):99-113. doi:10.1080/1065657X.2008. 10702364

Zajonc O, Frydrych J, Jezerska L (2014) Pelletization of compost for energy utilization. In: 2014 International conference on agricultural and biosystems engineering, IERI Procedia 8:2-10

Zalidis G, Stamatiadis S, Takavakoglou V, Eskridge K, Misopolinos N (2002) Impacts of agricultural practices on soil and water quality in the Mediterranean region and proposed assessment methodology. Agri Ecosys Environ 88:137-146. doi:10.1016/ S0167-8809(01)00249-3

Zhang L, Sun XY, Tian Y, Gong XQ (2013) Effects of brown sugar and calcium superphosphate on the secondary fermentation of green waste. Bioresour Technol 131:68-75. doi:10.1016/j. biortech.2012.10.059 